\title{
Low serum adiponectin concentrations are associated with insulin sensitivity independent of obesity in Sudanese subjects with type 2 diabetes mellitus
}

\author{
Moawia Abdelgadir ${ }^{1 *}$, Anders F Karlsson ${ }^{1}$, Lars Berglund ${ }^{2}$ and Christian Berne ${ }^{1}$
}

\begin{abstract}
Aims: Prevalence of Type 2 diabetes mellitus among Sudanese population was found to be $3.4 \%$ and associated with high rates of complications and obesity. Different adipocytokines are secreted from adipose tissues, among them adiponectin, which was shown to have insulins ensitizing properties and anti-inflammatory, anti-atherogenic effect. The aim of this study was to characterize type 2 diabetes in Sudanese diabetic subjects and controls in respect to hormones influencing or influenced by glucose metabolism.

Methods: 104 type 2 diabetic patients (45 men and 59 women), and 75 matched control subjects (34 men and 41 women) were studied. Fasting serum samples were used to measure adiponectin, leptin, insulin, proinsulin, ghrelin and glucose. Body mass index, insulin/proinsulin ratio and (HOMA) insulin resistance and beta cell function were also calculated.

Results: Adiponectin serum concentrations were significantly lower in subjects with type 2 diabetes compared with controls subjects $(P=0.002)$, comparison between males and females did not reach significant levels in both diabetic $(P=0.06)$ or controls $(P=0.16)$ groups. In the diabetic group adiponectin correlated positively with serum glucose, negatively with serum proinsulin and HOMA beta cell function $(P=0.03)$ respectively and serum ghrelin $(P=0.003)$, but not with $\mathrm{BMI}, \mathrm{HOMA}$ insulin resistance, insulin or leptin. In controls serum adiponectin correlated negatively with $\mathrm{BMI}(\mathrm{P}=0.002)$ but not with other variables.

Conclusions: The findings of this study suggest that, adiponectin concentrations independent on BMI as a measure of adiposity, were mostly linked to insulin sensitivity and not to insulin resistance in Sudanese type 2 diabetic subjects, where race specific regulation mechanisms or different type 2 diabetes phenotype suggested being a major contributory factor in clarification the findings of this study.
\end{abstract}

Keywords: Diabetes mellitus, Sudan, Adiponectin, Ghrelin, Leptin

\section{Introduction}

Impaired insulin secretion or/and abnormal insulin action and obesity are major characteristics for type 2 diabetes mellitus [1-3]. The prevalence of diabetes mellitus in the Sudanese population was 3.4\% and type 2 diabetes mellitus account for $75 \%$ of all diagnosed cases, among whom the majority also has a family history of diabetes [4] and $40 \%$

\footnotetext{
* Correspondence: moawia.abdelgadir@medsci.uu.se

'Department of Medical Sciences, Uppsala University Hospital, Uppsala SE.751 85, Sweden

Full list of author information is available at the end of the article
}

of them are obese [5] In a population based study $40 \%$ of the patients are found to be obese [5].

Adipose tissue was found to produce a variety of adipocytokines including leptin, adipsin and tumor necrosis factor [6-11]. Adiponectin is the recently identified most abundant among of them - is a $30 . \mathrm{kDa}$ protein [12-14]. Mechanisms of regulation of adiponectin proposed to be multifactorial. Involvements of genetic factors, glucocorticosteroids, body fat distribution and insulin have been shown in different studies [12,15,16]. Adiponectin serum levels were found to be lower in type 2 diabetes 
mellitus and obese subjects [14,17-19] and reversibly correlated with insulin resistance and measures of body fat [20-23]. Besides its insulin.sensitizing properties [23-25], adiponectin was also suggested to have an antiinflammatory, anti-atherogenic effect [26-28].

It is of interest to explore the association of adiponectin with metabolic parameters in different populations where ethnic diffrences were reported in som studies [29-34]. The aim of this study was to characterize type 2 diabetes in Sudanese diabetic subjects and controls in respect to hormones influencing or influenced by glucose metabolism.

\section{Research design and methods}

One hundred and four diabetic patients (males/females, 45/59) were recruited from the outpatient diabetes clinic at Omdurman Teaching Hospital, Khartoum, Sudan. Inclusion criteria were treatment with diet and/or oral hypoglycemic agents, age $>20$ years and duration of diabetes $>1$ year. They were treated with glibenclamide $(\mathrm{n}=80)$, glicalazide $(\mathrm{n}=1)$, metformin $(\mathrm{n}=4)$ and or diet alone $(n=19)$. A BMI and age matched group of 75 (males/females, 41/34) apparently healthy non diabetic subjects, who live in the same area, were selected as controls. Informed consent was obtained from all subjects. The and ethical clearance was taken from committee at The Federal Ministry of Health approved of the study. A questionnaire including personal details and clinical characteristics was completed for all subjects. Blood pressure, weight and height in light clothing without shoes were measured and body mass index (BMI) was calculated. In the fasting state blood samples were drawn for the determination of serum adiponectin, leptin, ghrelin, glucose, insulin and proinsulin. The samples were centrifuged within 2 hours after collection and kept frozen at $-20^{\circ} \mathrm{C}$ until analyzed at the Department of Medicine, Malmö University Hospital and Uppsala University Hospital, Sweden. The demographic and clinical characteristics of the subjects are shown in Table 1.

Adiponectin was analyzed using Human Adiponectin RIA kit (Linco Research, St. Charles, MO, USA) of assay specificity $<0.01 \%$, ghrelin was measured using Human Ghrelin RIA kit (Linco Research, St. Charles, MO, USA) of $100 \%$ specificity and leptin was measured using RIA kit (Linco Research, St. Charles, MO, USA), detecting immunoreactive human leptin with sensitivity $0,5 \mathrm{ng} / \mathrm{mL}$. Insulin was measured with specific RIA cross reacting with less than $0.2 \%$ proinsulin (Linko Research, St. Charles, MO, USA). Total serum proinsulin levels were measured using a goat antibody raised against human proinsulin, human proinsulin standards and 125I-human proinsulin as tracer (Linco Res. Inc.). This assay detects intact proinsulin (100\%) and des.31,32 proinsulin (95\%) but does not crossreact with insulin, C-peptide or des-64,65 proinsulin $(<0.1 \%)$. Serum glucose was analyzed using the
Table 1 Demographic and clinical characteristics of the subjects

\begin{tabular}{lll}
\hline Characteristics & Type 2 diabetes & Controls \\
\hline No. of subjects & 104 & 75 \\
Males/Females & $45 / 59$ & $34 / 41$ \\
Age $(\mathrm{yrs})$ & $53.8 \pm 10.7$ & $53.4 \pm 8.9(P=0.83)$ \\
BMI (kg/m2) & $23.5 \pm 5.3$ & $24.0 \pm 3.7(P=0.59)$ \\
Diabetes duration (yrs) & $9.9 \pm 7.9$ & - \\
Systolic BP (mmHg) & $117 \pm 14$ & $119 \pm 16.0(P=0.22)$ \\
Diastolic BP (mmHg) & $79 \pm 8$ & $80 \pm 10(P=0.71)$ \\
Adiponectin $(\mu \mathrm{g} / \mathrm{ml})$ & $7.54 \pm 4.62$ & $9.56 \pm 5.92(P=0.0017)$ \\
Gherlin $(\mu \mathrm{g} / \mathrm{ml})$ & $26.78 \pm 18.91$ & $26.64 \pm 8.78(P=0.99)$ \\
Leptin (ng/mL) & $9.6 \pm 7.9$ & $14.9 \pm 11.6(P=0.0066)$ \\
Glucose (mmol/L) & $8.6 \pm 4.4$ & $4.2 \pm 0.9(P=0.0001)$ \\
Insulin (pmol/L) & $75 \pm 47.0$ & $67.6 \pm 23.2(P=0.99)$ \\
Proinsulin $(\mathrm{pmol} / \mathrm{L})$ & $26.3 \pm 21.7$ & $17.8 \pm 12.8(P=0.0031)$ \\
Pl/insulin ratio & $0.38 \pm 0.30$ & $0.24 . \pm 0.12(P=0.0003)$ \\
HOMA IR & $6.15 \pm 0.92$ & $5.58 \pm 0.40(P=0.0001)$ \\
HOMA B & $2.82 \pm 1.26$ & $4.62 \pm 0.90(P=0.0001)$ \\
\hline
\end{tabular}

Mean \pm SD Abbreviations: $B P$, blood pressure; PI, proinsulin.

glucose oxidase technique. Homeostasis model assessment (HOMA) was used to assess pancreatic cell function (HOMA B) and insulin resistance (HOMA IR) using fasting insulin and glucose concentrations by the formula: HOMA-B (\%) $=20 \mathrm{X}$ [insulin]/(glucose.3,5) and HOMA-IR = insulin/(22,5e.ln[glucose]) [35].

\section{Statistical analysis}

All data were expressed as mean + SD. Statistical analysis was performed using the program SAS for Windows 6.12 (SAS Institute, Cary NC). T-test was used for comparison between groups for variables with normal or log normal distribution. Pearson's correlation coefficient was used to determine association with variables normal or log normal distribution. Adjustment calculated as Pearson's partial correlation coefficients.

\section{Results}

Table 1 shows the characteristics of the two study groups. Fasting adiponectin serum levels were significantly lower in diabetic subjects compared to controls (Table 1). However, differences did not reach significance when males and females in both diabetic $6.9 \pm 3.5$ vs. $8.4 \pm 5.2 \mu \mathrm{g} / \mathrm{ml}$, $(\mathrm{P}=0.06)$ and control $9.1 \pm 6.3$ vs. $10.2 \pm 5.4 \mu \mathrm{g} / \mathrm{ml}$, $(\mathrm{P}=0.16)$ groups where compared. Adiponectin did not correlate to $\mathrm{BMI}$ in diabetic group $(\mathrm{r}=-0.12, \mathrm{P}=0.24)$, but it correlated significantly negative in the control subjects $(\mathrm{r}=-0.38, \mathrm{P}=0.002)$.

Adiponectin concentrations correlated significantly negative with HOMA $\mathrm{B}$ in subjects with type 2 diabetes 
only $(\mathrm{r}=-0.21, \mathrm{P}=0.04)$, whereas no significant correlation to HOMA IR was found in subjects with type 2 diabetes $(r=0.08, P=0.44)$ or controls $(r=-0.16, P=0.33)$. Serum adiponectin in diabetic subjects did not correlate significantly with systolic $(\mathrm{r}=-0.13, \mathrm{P}=0.20)$ and diastolic $(\mathrm{r}=-0.13, \quad \mathrm{P}=0.20)$ blood pressure, this correlation remained non-significant after adjustment for BMI. In non-diabetic subjects, the systolic and diastolic blood pressures were not related to adiponectin concentrations.

Adiponectin levels correlated significantly negative to serum proinsulin in diabetic subjects $(\mathrm{r}=-0.22, \mathrm{P}=0.03)$, but not to insulin $(\mathrm{r}=-0.16, \mathrm{P}=0.12)$ or proinsulin/insulin ratio $(r=-0.18, P=0.06)$, whereas no correlation was seen between adiponectin and the insulin or proinsulin/insulin ratio in control subjects $(\mathrm{r}=0.03, \mathrm{P}=0.83)$ and $(\mathrm{r}=-0.01$, $\mathrm{P}=0.53)$.

Also serum adiponectin levels correlated significantly positive with serum glucose in diabetic subjects $(r=0.22$, $\mathrm{P}=0.03$ ), however no significance was found between adiponectin and serum glucose in control subjects $(\mathrm{r}=-0.1, \mathrm{P}=0.5)$.

Type 2 diabetic subjects treated by sulphonylurea, had almost the same levels of adiponectin $(7.3 \pm 4.6 \mu \mathrm{g} / \mathrm{ml}$, $\mathrm{n}=81$ ) compared to those treated with diet alone, or metformin $(7.6 \pm 4.7 \mu \mathrm{g} / \mathrm{ml}, \mathrm{n}=23, \mathrm{P}=0.99)$. Adjusting for BMI $(P=0.87)$ did not changed the results. The subjects treated with sulphonylurea had, however, also lower BMI than the other group, $(22.7 \pm 4.9$ versus $26.1 \pm 5.9, \mathrm{P}=0.0017)$, but no differences in HOMA B $(\mathrm{P}=0.28)$ or HOMA IR $(\mathrm{P}=0.15)$ was found. Fasting serum leptin levels did not correlate with adiponectin levels neither in diabetic $(r=0.03, P=0.73)$ nor in control $(\mathrm{r}=-0.01, \mathrm{P}=0.1)$ groups.

However, serum adiponectin level correlated significantly with serum ghrelin in diabetic subjects $(r=0.29$, $\mathrm{P}=0.003)$, but not in control subjects $(\mathrm{r}=0.18, \mathrm{P}=0.14)$.

\section{Discussion}

In agreement with previous reports adiponectin was found to be significantly lower in subjects with diabetes compared to controls [17-19]. However, in contrast with the studies that have shown that irrespective of ethnicity, adiponectin concentrations negatively correlated to BMI and insulin resistance in subjects with diabetes $[14,17,18,23]$. Our findings showed that adiponectin in diabetic subjects correlated positively with fasting glucose and negatively with fasting serum proinsulin and HOMA cell function but not with the insulin or HOMA insulin resistance or even BMI. In the control subjects adiponectin correlated negatively only with BMI. The difference in adiponectin concentrations and its association in both groups could be explained by the fact that adiponectin ameliorates insulin sensitivity, where healthy controls have significantly increased adiponectin levels, thus have significantly lower insulin resistance and better cell function (Table 1), and that goes in agreement with some studies [36]. However, the finding in this study that showed similar adiponectin levels in two diabetic subgroups (according to type of treatment) that have significantly different BMI, and have no differences in HOMA IR or HOMA B, could confirm the finding that adiponectin concentrations are linked also to insulin sensitivity [24,25] irrespective to measures of adiposity [36]. Relaying on the findings that adiponectin related to proinsulin and HOMA cell function in diabetic subjects, it would be useful to find whether there is a possible role of adiponectin in mediation hepatic IR and decreased cell function in type 2 diabetes, as has been recently demonstrated that the interaction between muscle and hepatic receptors through activation of AMP kinase could mediate adiponectin effects [37].

Besides, due to differences in fat distribution, as diabetics have less subcutaneous fat and increased visceral fat, lipotoxic effects could lead also to deterioration of pancreatic cell function and increased hepatic and peripheral insulin resistance in type 2 diabetes [38].

In both groups we did not observe significant gender differences in adiponectin concentrations [39]. Also no association was found between adiponectin and leptin and that is similar to a previous report [40]. Data on association between adiponectin and ghrelin in diabetes is scarce, and no correlation has been found in non diabetic subjects $[41,42]$. Serum adiponectin and ghrelin concentrations were found to be significantly correlated only in subjects with diabetes in this study, where ghrelin correlated significantly negative with fasting glucose in both diabetic $(r=0.21, P=0.03)$ and control subjects $(r=0.40$, $\mathrm{P}=0.008)$. The link between adiponectin and ghrelin in diabetic subjects could be through the hepatic glucose homeostasis, which is enhanced by ghrelin and suppressed by adiponectin [43]. Despite the generally known association between adiponectin and some metabolic and adiposity characteristics, the absence of this relationship as shown in this study, could support the hypothesis that adiponectin concentration could be regulated differently in different populations, particularly in populations with an African origin [29-34].

In conclusion, we showed in this study different association of adiponectin in Sudanese diabetic and healthy subjects, contrasting to other reports of different populations.

Adiponectin concentrations are mostly linked to insulin sensitivity independent on BMI as a measure of adiposity and not to insulin resistance in type 2 diabetic Sudanese subjects. Also adiponectin concentrations were linked to ghrelin levels in subjects with type 2 diabetes. However, race specific regulation mechanisms or a different type 2 diabetes phenotype could be factors in clarification the findings of this study. Further 
investigations among this population and population oriented approach to elucidate the mechanisms underlying these perturbations of adiponectin concentrations are required.

\section{Competing interests}

The authors declare that they have no competing interests.

\section{Authors' contributions}

(MA, AFK, LB and CB) contributed equally to this work. All authors read and approved the final manuscript.

\section{Acknowledgements}

We thank Margareta Ericson for excellent technical assistance, the staff of diabetes clinic, Omdurman Teaching Hospital, Sudan and the diabetic subjects for co-operation.

This work was supported by grants from Ernfors Fund and the Department of Medical Sciences, Uppsala University.

\section{Author details}

'Department of Medical Sciences, Uppsala University Hospital, Uppsala SE.751 85, Sweden. ${ }^{2}$ Uppsala Clinical Research Centre, Uppsala University Hospital, Uppsala, Sweden.

Received: 9 March 2012 Accepted: 7 March 2013

Published: 13 March 2013

\section{References}

1. Reaven GM: Role of insulin resistance in human disease. Diabetes 1988 , 37:1595-1607.

2. Mantozoros C, Flier J: Insulin resistance: the clinical spectrum. Adv Endocrinol Metab 1995, 19:193-232.

3. Lillioja S, Mott D, Spraul M, Ferraro R, Foley JE, Ravussin E, Knowler WC, Bennett PH, Bogardus C: Insulin resistance and insulin secretory dysfunction as precursors for noninsulin dependant diabetes mellitus. N Eng J Med 1993, 329:1988-1992.

4. Elbagir M, Eltom M, Elmehadi M, Kadam IM, Berne C: Population-based study of the prevalence of diabetes mellitus and impaired glucose tolerance in adults among in Northern Sudan. Diabetes Care 1996, 19:1126-1128

5. Elmehadi M, Abdel Rahman L, Mukhtar S: Patterns of diabetes mellitus in Sudan. Trop Geog Med 1989, 4:353-355.

6. Friedman JM, Halaas JL: Leptin and the regulation of body weight in mammals. Nature 1998, 395:763-770

7. Ahima RS, Flier JS: Adipose tissue as an endocrine organ. Trends Endocrinol Metab 2000, 11:327-332

8. Hotamisligil GS: The role of TNF-a and TNF receptors in obesity and insulin resistance. J Int Med 1999, 245:621-625.

9. Mohamed Ali V. Pinkney JH, Coppack SW: Adipose tissue as an endocrine and paracrine organ. Int J Obes Relat Metab Disord 1998, 22:1145-1158.

10. Scherer PE, Williams S, Fogliano M, Baldini G, Lodish HF: A novel serum protein similar to C1q, produced exclusively in adipocytes. J Biol Chem 1995, 270(45):26746-26749.

11. Maeda K, Okubo K, Shimomura I, Funahashi T, Matsuzawa Y, Matsubara K: CDNA cloning and expression of a novel adipose specific collagen-like factor, apM1 (AdiPose Most abundant Gene transcript 1). Biochem Biophys Res Commun 1996, 221 (2):286-289.

12. Hu E, Liang P, Spiegelman BM: AdipoQ is a novel adipose-specific gene dysregulated in obesity. J Biol Chem 1996, 271(18):10697-10703.

13. Comuzzie AG, Funahashi T, Sonnenberg G, Martin LJ, Jacob HJ, Black AE, Maas D, Takahashi M, Kihara S, Tanaka S, Matsuzawa Y, Blangero J, Cohen D, Kissebah A: The genetic basis of plasma variation in adiponectin, a global endophenotype for obesity and the metabolic syndrome. J Clin Endocrinol Metab 2001, 86(9):4321-4325.

14. Fasshauer M, Klein J, Neumann S, Eszlinger M, Paschke R: Hormonal regulation of adiponectin gene expression in $3 \mathrm{~T} 3-\mathrm{L} 1$ adipocytes. Biochem Biophys Res Commun 2002, 290(3):1084-1089.

15. Statnick MA, Beavers LS, Conner LJ, Corominola H, Johnson D, Hammond CD, Rafaeloff-Phail R, Seng T, Suter TM, Sluka JP, Ravussin E, Gadski RA, Caro
JF: Decreased expression of apM1 in omental and subcutaneous adipose tissue of humans with type 2 diabetes. Int J Exp Diabetes Res 2000, 1(2):81-88.

16. Halleux CM, Takahashi M, Delporte ML, Detry R, Funahashi T, Matsuzawa Y Brichard SM: Secretion of adiponectin and regulation of apM1 gene expression in human visceral adipose tissue. Biochem Biophys Res Commun 2001, 288(5):1102-1107.

17. Weyer C, Funahashi T, Tanaka S, Hotta K, Matsuzawa Y, Pratley RE, Tataranni PA: Hypoadiponectinemia in obesity and type 2 diabetes: close association with insulin resistance and hyperinsulinemia. J Clin Endocrinol Metab 2001, 86(5):1930-1935.

18. Hotta K, Funahashi T, Arita Y, Takahashi M, Matsuda M, Okamoto Y, Iwahashi H, Kuriyama H, Ouchi N, Maeda K, Nishida M, Kihara S, Sakai N, Nakajima T, Hasegawa K, Muraguchi M, Ohmoto Y, Nakamura T, Yamashita S, Hanafusa T, Matsuzawa Y: Plasma concentrations of a novel, adipose-specific protein, adiponectin, in type 2 diabetic patients. Arterioscler Thromb Vasc Biol 2000, 20(6):1595-1599.

19. Arita Y, Kihara S, Ouchi N, Takahashi M, Maeda K, Miyagawa J, Hotta K, Shimomura I, Nakamura T, Miyaoka K, Kuriyama H, Nishida M, Yamashita S, Okubo K, Matsubara K, Muraguchi M, Ohmoto Y, Funahashi T, Matsuzawa Y: Paradoxical decrease of an adipose-specific protein, adiponectin, in obesity. Biochem Biophys Res Commun 1999, 257(1):79-83.

20. Cnop M, Havel PJ, Utzschneider KM, Carr DB, Sinha MK, Boyko EJ, Retzlaff BM, Knopp RH, Brunzell JD, Kahn SE: Relationship of adiponectin to body fat distribution, insulin sensitivity and plasma lipoproteins: evidence for independent roles of age and sex. Diabetologia 2003, 46(4):459-469.

21. Yamamoto Y, Hirose H, Saito I, Tomita M, Taniyama M, Matsubara K, Okazaki Y, Ishii T, Nishikai K, Saruta T: Correlation of the adipocyte-derived protein adiponectin with insulin resistance index and serum high-density lipoprotein-cholesterol, independent of body mass index, in the Japanese population. Clin Sci (Lond) 2002, 103(2):137-142.

22. Matsubara M, Maruoka S, Katayose S: Inverse relationship between plasma adiponectin and leptin concentrations in normal-weight and obese women. Eur J Endocrinol 2002, 147(2):173-180.

23. Stefan N, Vozarova B, Funahashi T, Matsuzawa Y, Weyer C, Lindsay RS, Youngren JF, Havel PJ, Pratley RE, Bogardus C, Tataranni PA: Plasma adiponectin concentration is associated with skeletal muscle insulin receptor tyrosine phosphorylation, and low plasma concentration precedes a decrease in whole-body insulin sensitivity in humans. Diabetes 2002, 51(6):1884-1888.

24. Yamauchi T, Kamon J, Waki H, Terauchi Y, Kubota N, Hara K, Mori Y, Ide T, Murakami K, Tsuboyama-Kasaoka N, Ezaki O, Akanuma Y, Gavrilova O, Vinson C, Reitman ML, Kagechika H, Shudo K, Yoda M, Nakano Y, Tobe K, Nagai R, Kimura S, Tomita M, Froguel P, Kadowaki T: The fat-derived hormone adiponectin reverses insulin resistance associated with both lipoatrophy and obesity. Nat Med 2001, 7(8):941-946.

25. Kubota N, Terauchi Y, Yamauchi T, Kubota T, Moroi M, Matsui J, Eto K, Yamashita T, Kamon J, Satoh H, Yano W, Froguel P, Nagai R, Kimura S, Kadowaki T, Noda T: Disruption of adiponectin causes insulin resistance and neointimal formation. J Biol Chem 2002, 277(29):25863-25866.

26. Yokota T, Oritani K, Takahashi I, Ishikawa J, Matsuyama A, Ouchi N, Kihara S, Funahashi T, Tenner AJ, Tomiyama Y, Matsuzawa Y: Adiponectin, a new member of the family of soluble defense collagens, negatively regulates the growth of myelomonocytic progenitors and the functions of macrophages. Blood 2000, 96(5):1723-1732

27. Ouchi N, Kihara S, Arita Y, Okamoto Y, Maeda K, Kuriyama H, Hotta K, Nishida M, Takahashi M, Muraguchi M, Ohmoto Y, Nakamura T, Yamashita S, Funahashi T, Matsuzawa Y: Adiponectin, an adipocyte-derived plasma protein, inhibits endothelial NF-kappaB signaling through a cAMP-dependent pathway. Circulation 2000, 102(11):1296-1301.

28. Ouchi N, Kihara S, Arita Y, Nishida M, Matsuyama A, Okamoto Y, Ishigami M, Kuriyama H, Kishida K, Nishizawa H, Hotta K, Muraguchi M, Ohmoto Y, Yamashita S, Funahashi T, Matsuzawa Y: Adipocyte-derived plasma protein, adiponectin, suppresses lipid accumulation and class A scavenger receptor expression in human monocyte-derived macrophages. Circulation 2001, 103(8):1057-1063.

29. Hulver MW, Saleh O, MacDonald KG, Pories WJ, Barakat HA: Ethnic differences in adiponectin levels. Metabolism 2004, 53(1):1-3.

30. Osei K, Gaillard T, Kaplow J, Bullock M, Schuster D: Effects of rosglitazone on plasma adiponectin, insulin sensitivity, and insulin secretion in high-risk African Americans with impaired glucose tolerance test and type 2 diabetes. Metabolism 2004, 53(12):1552-1557. 
31. Koebnick C, Roberts CK, Shaibi GQ, Kelly LA, Lane CJ, Toledo-Corral CM, Davis JN, Ventura EE, Alexander K, Weigensberg MJ, Goran MI: Adiponectin and leptin are independently associated with insulin sensitivity, but not with insulin secretion or beta-cell function in overweight Hispanic adolescents. Horm Metab Res 2008, 40(10):708-712.

32. Mente A, Razak F, Blankenberg S, Vuksan V, Davis AD, Miller R, Teo K, Gerstein H, Sharma AM, Yusuf S, Anand SS, Study of the Health Assessment And Risk Evaluation; Study of the Health Assessment And Risk Evaluation in Aboriginal Peoples Investigators: Ethnic variation in adiponectin and leptin levels and their association with adiposity and insulin resistance. Diabetes Care 2010, 33(7):1629-1634.

33. Khoo CM, Sairazi S, Taslim S, Gardner D, Wu Y, Lee J, Van Dam RM, Shyong TE: Ethnicity modifies the relationships of insulin resistance, inflammation, and adiponectin with obesity in a multiethnic Asian population. Diabetes Care 2011, 34(5):1120-1126.

34. Pereira RI, Wang CC, Hosokawa P, Dickinson LM, Chonchol M, Krantz MJ, Steiner JF, Bessesen DH, Havranek EP, Long CS: Circulating adiponectin levels are lower in Latino versus non-Latino white patients at risk for cardiovascular disease, independent of adiposity measures. BMC Endocr Disord. 2011, 11:13

35. Matthews D, Hosker J, Rudenski A, Naylor BA, Treacher DF, Turner RC: Homeostasis model assessment: insulin resistance and B-cell function from fasting glucose and insulin concentrations in man. Diabetologia 1985, 28:412-419.

36. Ferris WF, Naran NH, Crowther NJ, Rheeder P, van der Merwe L, Chetty N: The relationship between insulin sensitivity and serum adiponectin levels in three population groups. Horm Metab Res 2005, 37(11):695-701.

37. Tschritter O, Fritsche A, Thamer C, Haap M, Shirkavand F, Rahe S, Staiger H, Maerker E, Haring H, Stumvoll M: Plasma adiponectin concentrations predict insulin sensitivity of both glucose and lipid metabolism. Diabetes 2003, 52(2):239-243.

38. Gil-Campos M, Canete RR, Gil A: Adiponectin, the missing link in insulin resistance and obesity. Clin Nutr 2004, 23(5):963-974.

39. Bergman RN, Mittelman SD: Central role of the adipocyte in insulin resistance. J Basic Clin Physiol Pharmacol 1998, 9:205-221.

40. Putz DM, Goldner WS, Bar RS, Haynes WG, Sivitz WI: Adiponectin and C-reactive protein in obesity, type 2 diabetes, and monodrug therapy. Metabolism 2004, 53(11):1454-1461.

41. Gavrila A, Chan JA, Yiannakouris N, Kontogiani M, Miller LC, Orlova C, Mantozoros CS: Serum adiponectin levels are inversely associated with overall and central fat distribution but are not directly regulated by acute fasting or leptin administration in humans: Cross-sectional and interventional studies. J Clin Endocrinol Metab 2003, 88(10):4823-4831.

42. Choi KM, Lee J, Lee KW, Seo JA, Oh JH, Kim SG, Kim NH, Choi DS, Baik SH: The associations between plasma adiponectin, ghrelin levels and cardiovascular risk factors. Eur J Endocrinol 2004, 150(5):715-718.

43. Holdstock C, Engstrom BE, Ohrvall M, Lind L, Sundbom M, Karlsson FA: Effect of bariatric surgery on adipose tissue regulatory peptides and growth hormone secretion. Asia Pac J Clin Nutr 2004, 13:S41.

doi:10.1186/1758-5996-5-15

Cite this article as: Abdelgadir et al:: Low serum adiponectin concentrations are associated with insulin sensitivity independent of obesity in Sudanese subjects with type 2 diabetes mellitus. Diabetology \& Metabolic Syndrome 2013 5:15.

\section{Submit your next manuscript to BioMed Central and take full advantage of:}

- Convenient online submission

- Thorough peer review

- No space constraints or color figure charges

- Immediate publication on acceptance

- Inclusion in PubMed, CAS, Scopus and Google Scholar

- Research which is freely available for redistribution

Submit your manuscript at www.biomedcentral.com/submit
C Biomed Central 